of nuclei in the anther tapetal layer in species of Cucurbita, Aconitum and Valeriana. Up to a certain point the tapetum consists of normal uninucleate cells, but about the time of the prophase of meiotic divisions in the pollen-mother-cells some unusual cytological developments are induced: while some of the trpetal cells and their nuclei remain as before, others may become polynucleate, and yet others may show more or less conspicuous enlargement and, by endomitosis, may give rise to nuclei of different size categories corresponding to $4 n, 8 n$, and even $16 n$ chromosomes complements. These developments, described by these authors as "the differentiation of the tapetal cells", are considered to result from successive stimuli which can be related to developmental changes in the developing pollen-mother-cells and the tetrads to which they give rise. On the evidence to date, based on species drawn from widely separated families, it appears that these seemingly anomalous developments in the tapetum may well prove to be of very general occurrence. The texts are in English throughout, with bilingual titles. The journal is well produced, with a good clear type, and is illustrated by line drawings and by photographic plates of good quality.

Link between the Annelids and the Arthropods ?

A NEwLy FOUND fossil from near the base of the Cambrian of South Australia shows affinities which may throw some light on the origin of the arthropods. The new form is described by M. F. Glaessner in the Transactions of the Royal Society of South Australia $(81,185 ; 1958)$ and has been named Spriggina floundersi. It represents a new family of the poly. chaete annelids. The body is flat, the head being without external segmentation and having lateral extensions giving it a roughly horseshoe shape, the trunk consisting of a very gently tapering series of segments with appendages terminating in bristles, numbering up to about 40 and not differentiated into a tail. The largest specimen measured $46 \mathrm{~mm}$. long and $11 \mathrm{~mm}$. wide. Since fossil jellyfish are found at the same locality it is not necessary to assume that Spriggina was hard-bodied. Certain features of the head resemble those of the living group Tomopteridae, members of which are pelagic. It is accordingly suggested that the aberrant pelagic adaptations of the Tomopteridae may conceal more primitive characters. In particular the lateral extensions of the head of Tomopteris and its composite nature may foreshadow the formation of primitive arthropod head shields such as those of the Middle Cambrian proarthropod (trilobitomorph) Marrella, and of trilobite larvæ or primitive trilobites. This possibility does not seem to have been considered by the zoologists.

\section{The Fairy Fly}

Prestwichia aquatica, the fairy fly, is a hymenopterous insect which parasitizes the eggs of aquatic insects, especially water-beetles, including Dytiscus marginalis L. It was first discovered by Sir John Lubbock in 1864 in a pond in Kent and was not seen again for thirty years, when Frederic Enock found a few specimens in a horse-pond. In 1896, and again in 1898, Enock records that he was able to find aquatic insect eggs containing both male and female specimens of Prestwichia aquatica, which eventually he reared. The eggs were taken from the previous year's stems of the water-plaintain, Alisma plantagoaquatica L. In a communication to the Journal of the Quekett Microscopical Club (28, No. 4; 1958), C. I. Ison writes that, since the work of Enock, Prestwichia has probably been found only on two occasions in Great Britain. The most recent was at Loughton, Essex, on July 17, 1958, when Ison saw two female fairy flies emerge from an unidentified egg. The males are much slower in emerging. Subsequent observations showed that twenty-six days elapsed before any movement of the parasites was noticed in the host egg after oviposition, and it was twenty-eight days before any females emerged. From one 2-mm. egg of the beetle, Ilybius ater, five male and twelve female fairy flies emerged. Observation of Prestwichia aquatica at the surface film of the water showed that they are quite at home whether they are above the film in the air or below, in the water, walking upside down.

\section{Predatory Animals in Spain}

DURING the past four years organized campaigns against predators have been taking place in Spain (Oryx, 5, No. 1; April 1959). Among the 100,000 mammals and birds killed were 36 martens, I,051 wild eats, 55 lynxes, 380 badgers, 7,250 eagles and other birds of prey. Such indiscriminate slaughter can only lead to extermination of the rarer species, especially, for example, of the southern race of the Spanish lynx, which is chiefly a lowland animal. Both the imperial eagle and the short-toed eagle, which lays only one egg, nest in easily accessible places and are especially vulnerable. In Spain there is as yet little interest in the preservation of wild life, and the conservation laws are not enforced effectively. Every predator is believed to be an enemy. A new conservation law will remove both the lynx and the lammergeier from the list of vermin, and will give the lammergeier complete protection for five years.

\section{Banana Wilt Investigations}

IN extended investigations of the vascular wilt disease of bananas caused by Fusarium oxysporum $\mathrm{f}$. cubense, R. H. Stover has examined the evidence for clonal differentiation among wild type isolates of the pathogen (Canad. J. Bot., 37, No. $2 ; 1959$ ). $F$. oxysporum f. cubense exists in diseased rhizomes and pseudostems of Gros Michel bananas in two major clonal groups, or cultivars, designated 'Odoratum' and 'Inodoratum', because of the presence or absence of a distinctive odour from cultures after 4-8 days on various media. Three clones of the 'Inodoratum' cultivar, which are difficult to distinguish morphologically on peptone dextrose agar, were, however, distinguishable by cultural interaction and pathogenicity tests in the field. Also, some clones of the 'Inodoratum' and 'Odoratum' cultivars have been shown to differ quantitatively in pathogenicity in the field. Clone $C$ from Honduras, of limited distribution, induced the most rapid disease-spread and destruction of banana mats, followed by clone $E$ from Panama. There wes an association between the 'Inodoratum' and 'Odoratum' cultivars and the syndromes induced in Honduras: the former usually induced strong yellowing of erect leaves, whereas the latter usually induced leaf collapse at the petiole with little or no leaf yellowing.

\section{Exhibition of Old-time Beekeeping}

AN interesting exhibition of equipment used by old-time beekeepers in connexion with their ancient craft is open until the end of September at the 